\title{
TEACHERS' EXPERIENCES AND PERCEPTIONS REGARDING MOBILE AUGMENTED REALITY GAMES: A CASE STUDY OF A TEACHER TRAINING
}

\author{
M.M. Marques, L. Pombo \\ Research Centre on Didactics and Technology in the Education of Trainers (CIDTFF) \\ Department of Education and Psychology, University of Aveiro (PORTUGAL)
}

\begin{abstract}
The literature has been recognizing the potential of mobile technologies, augmented reality (AR) and game-based approaches in Education and recommends its adoption. Considering the scarcity of this type of educational resources in the Portuguese context, it is relevant to create opportunities for teachers and researchers to collaborate in the development of high-quality open resources to be integrated into games available for all. To this end, a 50-hour continuous training course for teachers was conducted to promote collaborative development of mobile AR game-based resources for Science, Technology, Engineering and Mathematics learning. In this contribution, data from a questionnaire applied at the beginning of the training is analysed to support assessment of teachers' previous experiences and initial perceptions regarding mobile learning, AR use in Education and game-based learning. The questionnaire was anonymous and 14 out of 16 teachers gave informed consent to participate in this study. This data was triangulated with information collected through participant observation from two researchers who were also the trainers and the authors of this paper. Results reveal that teachers with different profiles attained this training. Nevertheless, most teachers revealed naïve perspectives on mobile and game-based learning and were unaware of AR technologies and their potential use in education. Teacher profiles varied from those who acknowledge not knowing and not using either of the three approaches in their teaching practices, nor in their personal learning experiences, to those who seem to have somewhat accurate ideas. This work is relevant as this case study is an empirical account of teachers practices and perspectives on mobile AR games.
\end{abstract}

Keywords: mobile learning; augmented reality; game-based learning; teacher perspectives; teacher practices; teacher training; case study.

\section{INTRODUCTION}

Mobile technologies such as tablets, smartphones and laptops have become more popular among students. Given the accessibility and user-friendly nature of mobile devices, students have become more confident by using mobile technologies [1]. In addition, the literature has been recognizing the potential of mobile technologies, as they may increase student engagement, collaboration, and access to unlimited resources beyond the information in the textbook [2], [3].

With the mobile technology widespread, new functionalities are being integrated in devices, namely augmented reality (AR), which can be used to enhance learning. Combining mobile AR learning with game-based approaches supports new teaching strategies in the outdoors and students' engagement and motivation for learning are enhanced (Pombo \& Marques, 2020). However, new practices require teacher training, as teachers are often reluctant to use or integrate them into their science curriculum (Ertmer \& Ottenbreit-Leftwich, 2010; Pombo et al., 2019). Additionally, there is a scarcity of educational resources, such as educational mobile games, which integrate curriculum contents. Considering this scarcity, the EduPARK project (http://edupark.web.ua.pt/) created an app that integrates AR contents, games and outdoor environments to promote interdisciplinary, contextualized and authentic learning, which have been revealing a high usability and educational value (Pombo \& Marques, 2019). The project has developed short-term training actions as well, but the integration of technologies in educational practices requires longer training that prompts teachers to create contents and games and not just use them in the classroom. 
Considering the above, a 50-hour workshop, a certified continuous training for teachers, was conducted to promote collaborative development of mobile AR game-based resources for Science, Technology, Engineering and Mathematics learning. This type of courses is relevant to create opportunities for teachers and researchers to collaborate in the development of high-quality open resources to be integrated into games that will be available for all. The workshop proposes the design, construction, and operation of science education resources, which can be integrated into apps, such as EduPARK. The quality and relevance of the resources produced is supported by the integration of recommendations from the literature on effective teaching and learning methodologies, particularly when seeking to take advantage of the potential of technologies. The produced resources are articulated with the National Science Curriculum and grounded in real educational contexts.

The next sections briefly present and discuss the methodology; the results concerning teachers' motivations and expectations for the workshop, conditions for technology use and mobile, augmented reality and game-based learning topics; and finally, the conclusion, with the final remarks, and recommendations for future work.

\section{METHODOLOGY}

This study is developed under a case study [8] of the development process of educational resources by in-service teachers during a 50-hour workshop (25-hour face to face and 25-hour autonomous work). The workshop aimed to promote the collaborative development of open digital educational resources that foster STEM learning based on game and supported by mobile devices.

The research question that guided the work reported in this contribution is: How are teacher-trainees characterized in terms of motivation and expectations for the workshop, conditions for the use of technologies in their schools, and previous experiences and perceptions on mobile learning, AR use in Education, and game-based learning? The characterization of the teacher-trainees serves a double purpose: a) to support the implementation of the training workshop, that is, to adapt the teaching and learning processes according to the identified needs, and b) to capture teachers' initial perspectives in order to evaluate the impact of the workshop in their opinions regarding integrating mobile, AR and game-based in teaching practices. Hence, an adaptative online questionnaire was applied at the beginning of the workshop and it was composed by a mixture of closed-ended and open-ended questions that were shown to respondents accordingly previous answers. The questionnaire is comprised by six sections, as follows:

1 motivations and expectations, with a multiple options selection question on motivations to attend the workshop and an open-ended question on expectations;

2 conditions for the use of digital technologies in the teacher's educational context, with a few closed-ended questions on the types of digital technologies available for their practice, for students' learning and school policy on mobile devices use, and also an optional open-ended question for additional comments on this topic;

3 workshop topics on: i) mobile learning, ii) AR use in Education, and iii) game-based-learning; all the topics with a mixture of open and closed-ended questions for data collection on teachertrainees' basic knowledge, previous experience and frequency of use, perceptions about advantages and disadvantages, and additional comments on the topic;

4 demographic data, collected anonymously, such as gender, academic qualifications, years of teaching experience, subjects and school years teachers were teaching, and median number of students in their classes.

Questionnaire data was analyzed through descriptive statistics and through content analysis. This data was triangulated with information collected through participant observation from two researchers who were also the trainers and the authors of this paper.

\subsection{Study participants}

The questionnaire included a closed-ended question asking respondents if they accepted the data provided through this tool to be used for research purposes. Fourteen out of 16 teachers attending the workshop gave informed consent to participate in this study, being 12 females and 2 males.

Ten teachers had high degree, mandatory by Portuguese Law, one had post-graduation course and three had master's degree. All teachers were experienced, as two had between 11 to 20 years of 
experience, eight had between 21 and 30 years, and four had more than 31 years of experience. This teacher cohort reflects very closely the Portuguese teacher profile [9], [10] in terms of gender and experience.

Three teachers lectured Mathematics in the $3^{\text {rd }}$ cycle of basic education (CBE, corresponding to school years 7 to 9) or in Secondary Teaching (ST, years 10 to 12), six teachers lectured Physics and Chemistry in the $3^{\text {rd }} \mathrm{CBE}$ or in SE, one teacher lectured Nature Sciences in the $3^{\text {rd }} \mathrm{CBE}$, and six teachers lectured Mathematics or Nature Sciences in the $2^{\text {nd }}$ CBE (years 5 and 6 ). Their classes varied from 16 to 20 students (4 teachers), 21 to 25 students (4), and 26 to 30 students (4).

\section{RESULTS}

This section is organized according to the sections of the data collection tool: the questionnaire.

\subsection{Teachers' motivations and expectations for the workshop}

In the closed-ended question for reasons to attend the workshop, the participant teachers selected: "Updating or acquiring knowledge" and "Possibility to have access to new resources" with 12 mentions each; "Combination of the workshop topics", "Possibility of changing teaching practice" and "Professional valorization", all with 10 mentions each. In common with previous studies [5], [11] is the relevance given to the resources access through training, again in experienced cohorts of teachers. Moreover, in the open-ended question on their expectations regarding the workshop, teachers presented an average of two, with a minimum of one to a maximum of five different expectations. Table 1 summarizes teachers' expectations. Not surprisingly, teachers mentioned they expected to learn ( 9 mentions) to improve their teacher practice ( 7 mentions) and, consequently, to have impact on students' motivation to learn (6), achievement (3) and behavior (1). Three teachers also mentioned they were curious about the workshop topics.

Table 1. Reported teachers' expectations for the workshop.

\begin{tabular}{l|l|c}
\hline \hline \multicolumn{1}{c|}{ Expectations } & \multicolumn{1}{c|}{ Example of citation } & Frequency \\
\hline To learn & $\begin{array}{l}\text { To develop competencies in areas where } \\
\text { I have some gaps, due to lack of time to } \\
\text { study and search autonomously. Q5 }\end{array}$ & 9 \\
\hline To improve the teaching practice & $\begin{array}{l}\text { To teach differently given the challenges } \\
\text { I face every day in the classroom. Q15 }\end{array}$ & 7 \\
\hline $\begin{array}{l}\text { To increase students' motivation/ } \\
\text { engagement with learning }\end{array}$ & To Increase my students' motivation. Q6 & 6 \\
\hline To promote students' learning & $\begin{array}{l}\text {.. to promote changes in their [students] } \\
\text { learning and in the results obtained. Q12 }\end{array}$ & 3 \\
\hline To improve students' behaviour & $\begin{array}{l}\text { I hope in the end to be able to promote } \\
\text { changes in students' behaviour... Q2 }\end{array}$ & 1 \\
\hline To satisfy curiosity & $\begin{array}{l}\text { I have a great curiosity in activities } \\
\text { outside the classroom. Q7 }\end{array}$ & 3 \\
\hline \hline
\end{tabular}

\subsection{Conditions for technology use}

The questionnaire results indicate that participating teachers and their students had conditions from the technological point of view (see Figure 1), with students having lower access than teachers. All teachers reported to have datashow in the classroom and seven had interactive board. Students' access to these resources is lower, only two and five, respectively. 


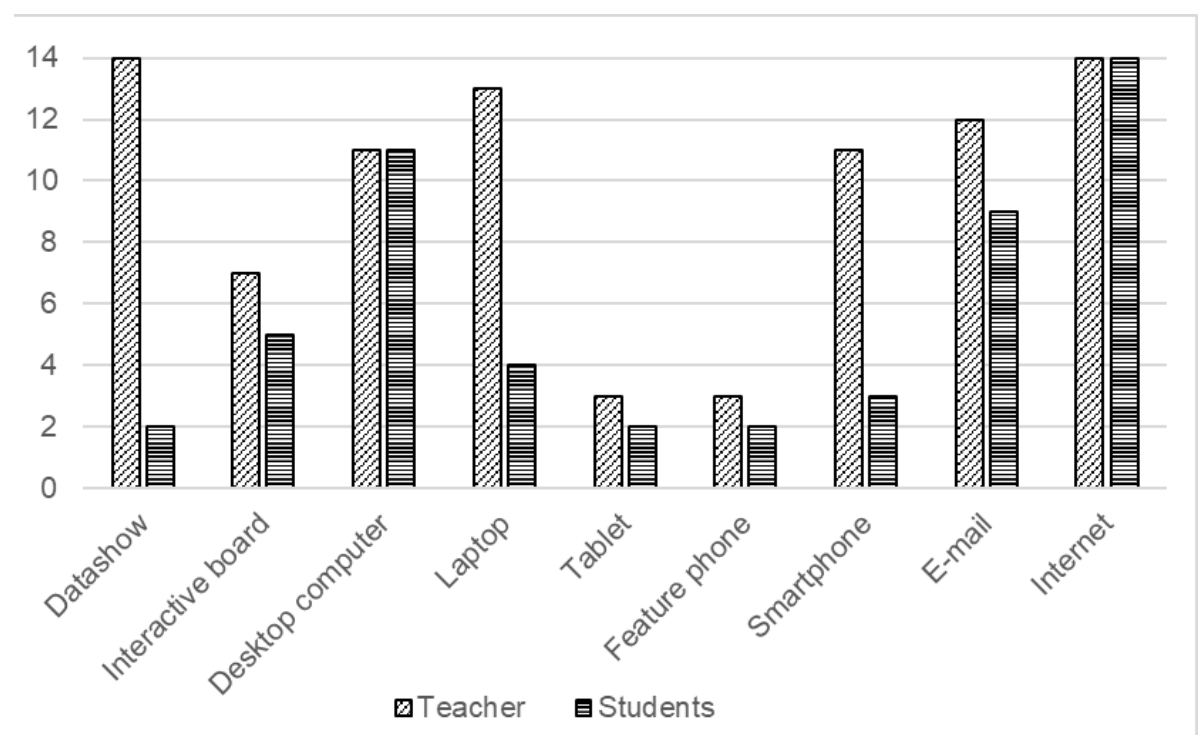

Figure 1. Reported technological conditions for teachers and their students.

All teachers mentioned having computer access for their teaching practices, either in desk, portable or tablet, and the same applies for the students of 12 of the 14 respondents. One teacher, who in a previous question reported tablets and laptop access only for teachers, in the open-ended question highlights it is unreliable technology:

"The school has some laptops and some tablets, not always in the best conditions and some rooms have a desktop computer. All classrooms have a projector, but teachers need to use their own laptops." (Q5)

Twelve teachers reported having either a feature phone (2) or a smartphone (10) and one stated having both. Schools provided students' access to these mobile phones in only five cases, in this cohort. Also, 12 teachers mentioned having email account, whereas nine respondents revealed their students had access to email accounts.

Although the results revealed that teachers and students mostly had access to technology to use in the school, 11 classified the technology as reasonable, one as bad and another as good. It is worth nothing that one teacher mentioned his/her school did not provide students access to any type of the considered technology, providing only internet access. The 2019 State of Education Report [12] mentions the wear and tear of the Portuguese schools' computer park as, in 2018/2019, the percentage of computers older than three years is very significant $(83.7 \%)$.

All respondents reported Internet access for them and for their students, although classifying it as reasonable (13), feeling some constraints in its use, such as slowness, insecurity, among others. Only one teacher classified the school internet connection as good. This is in line with the State of Education Report [12], which mentions the internet fragility in majority of schools.

As to the school policy on mobile devices use in classrooms, seven teachers mentioned it is allowed, five say it is forbidden and two acknowledge not knowing. One step further, six respondents mention that the school provides guidance to students on the proper use of mobile devices, five reports this does not happens in their school and three do not know.

\subsection{Teachers' previous experiences and perceptions on mobile learning}

When asked about the meaning of mobile learning, one teacher acknowledged not knowing: "...I have no idea what it is. That's why I signed up." Q1. Three teachers presented definitions considered incorrect, for example: "Education system using mobile devices." Q9. Another two teachers revealed notions with some incorrection, for example "Learning that is supported by new education technologies." (Q8). Finally, eight teachers presented simple definitions focused on mobile learning's technological dimension, as illustrates the following citation: "Learning using mobile devices (mobile phones, tablets, etc.)" Q4.

When questioned about examples of mobile learning projects or initiatives, one teacher mentioned seven examples (three with mobile apps, two with online platforms not specifically for mobile devices 
and two not specified), four acknowledged not knowing and eight mentioned, at least, one educational mobile app example. These were: EduPARK (4 mentions), Plikers (3), Kahoot (1), and MilageAprender+ (1) for mobile apps; Khan Academy (2), Wall Street English course (1), Tracker (1), and eTwining (1) for examples not specifically for mobile devices; and virtual lab and app to capture and measure sound ( 1 each) were the not specified ones.

All teachers mentioned having previous experience in mobile devices use for their own learning. However, only six described one (type of) experience where they had learnt with mobile devices (e.g., "In a short training within the scope of EduPARK." Q4), four described one experience where they had promoted the use of mobile devices for students' learning (e.g., "Making a Kahoot of the topics under study and playing with the students." Q5), and four did not provide a valid experience (e.g., "I signed up for a workshop via Telegram." Q7).

Regarding the frequency with which teachers claim promoting mobile learning, two teachers selected "very often (for example, almost every day of classes per class)", three selected "periodically (for example, twice a month per class)", six selected "sometimes" and three selected "never used". These results are aligned with a previous study [5], which may indicate that teachers are starting to integrate mobile learning into their practices, as advocated by several Horizon Reports ([13]-[15] and indicated in the State of Education Report [12, p. 321]: "Mobile devices (smartphone, tablet, etc.) have been progressively integrated into formal education systems", being the use of personal mobile devices in formal education by Portuguese students below of the European average.

From the 11 teachers that promoted mobile learning at least once, six presented valid examples (e.g., "I use the smartphone for the application of sonometer ( $8^{\text {th }}$ grade), where students learn effectively." Q9), four gave examples that can be explored, or not, with mobile devices (e.g., "I record videos on Facebook to show students and use Youtube" Q7) and one gave an example of teacher using mobile devices ("I use a smartphone application daily to simulate a graphing calculator." Q14).

Teachers that never used mobile devices in their teaching practices mentioned that they could change that attitude because they believe it may increase students' motivation for learn ("Students motivation in using mobile devices" Q6, and "To be able to motivate students for Mathematics and to be able to overcome the Mathematics' taboo for many students." Q15) and to their relevance, and availability to all ("The fact that mobile devices are nowadays indispensable instruments from students' point of view, are easy to use and accessible to everyone." Q4)

Teachers reported one (6 teachers), two (5 teachers) or three mobile learning advantages ( 3 teachers), in a total of 26. Table 2 presents the themes of teachers' responses to this open-ended question. Similarly to a previous study [11], motivation, availability (it is easy to carry around), and easiness in finding information stand out. However, some advantages frequently selected by teachers in the previous study [11] were not mentioned by this study's cohort: "the information is up-to-date", "does not waste paper", "it facilitates teachers work, namely in assessment" and "promotes digital competencies".

Table 2. Advantages of mobile learning, according to the participant teachers.

\begin{tabular}{l|l|c}
\hline \multicolumn{1}{c|}{ Advantage theme } & \multicolumn{1}{c}{ Example of citation } & Frequency \\
\hline Motivates students to learn & $\begin{array}{l}\text { An advantage will be the educational resources that are } \\
\text { taken from these devices to motivate students, .. Q9 }\end{array}$ & 9 \\
\hline Technology availability & $\begin{array}{l}\text { Nobody forgets the smartphone and so you can always } \\
\text { work. Q14 }\end{array}$ & 4 \\
\hline It is easy or quick to find information & The visual and interactive allow faster learning. Q6 & 4 \\
\hline Learning in a fun way & Fun combined with learning. Q8 & 2 \\
\hline $\begin{array}{l}\text { Diversifies teaching/learning } \\
\text { methodologies }\end{array}$ & $\begin{array}{l}\text { The fact that students can discover new ways of learning } \\
\text { through instruments that they often use in their daily lives. Q4 }\end{array}$ & 2 \\
\hline Supports higher interaction & Students interact more. Q5 & 2 \\
\hline $\begin{array}{l}\text { Taking advantage of an available up- } \\
\text { to-date technology }\end{array}$ & $\begin{array}{l}\text { Students' mobile devices are always up to date and always } \\
\text { modern. Q15 }\end{array}$ & 2 \\
\hline Better learning & $\begin{array}{l}\text { They allow the exploration of content in different ways, } \\
\text { according to the needs / intentions of each user. Q13 }\end{array}$ & 1 \\
\hline \hline
\end{tabular}


Teachers reported one ( 5 teachers), two (2 teachers) or three mobile learning barriers/constraints ( 7 teachers), in a total of 30 . Table 3 presents the themes of teachers' responses to this open-ended question. Students' lack of access to mobile devices, potential distractions and low-quality Internet are among the main barriers pointed. As teachers generally indicated more constraints than advantages, this may indicate a negative perspective towards mobile devices in their practices. This result crashes with a previous study [11] results where teachers selected more benefits than constraints in closedended questions. In that study, teachers selected a different set of barriers, such as "increased battery consumption", "mobile device dependence" and "prohibition of mobile device use in classes".

Table 3. Barriers/constraints of mobile learning, according to the participant teachers.

\begin{tabular}{l|l|c}
\hline \multicolumn{1}{c|}{ Barriers/constraints theme } & \multicolumn{1}{|c}{ Example of citation } & Frequency \\
\hline $\begin{array}{l}\text { Lack of access to mobile devices and } \\
\text { their diversity }\end{array}$ & $\begin{array}{l}\text { Students' little economic resources to purchase mobile } \\
\text { devices. Q8 }\end{array}$ & 7 \\
\hline Lack of (quality) Internet connection & $\begin{array}{l}\text { The fact that the Internet goes down and can generate } \\
\text { demotivation in students. Q5 }\end{array}$ & 6 \\
\hline Access to distractions & May cause distractions. Q16 & 6 \\
\hline $\begin{array}{l}\text { Lack of digital competence (teachers and } \\
\text { students) }\end{array}$ & $\begin{array}{l}\text { Not being so familiar. The speed with this "world" } \\
\text { evolves and my reduced speed to accompany it. Q1 }\end{array}$ & 4 \\
\hline Effort in information analysis & $\begin{array}{l}\text { It is necessary to evaluate the veracity of the } \\
\text { information. Q7 }\end{array}$ & 2 \\
\hline Prohibition of mobile devices use in class & No consent for mobile devices use. Q2 & 2 \\
\hline
\end{tabular}

\subsection{Teachers' previous experiences and perceptions on augmented reality}

When asked about the meaning of AR, four teachers acknowledged not knowing. Seven teachers presented definitions considered incorrect, for example: "The use of digital resources about reality" Q3. Finally, three teachers presented simple but correct definitions, as illustrates the following citation: "Augmented reality is something that mixes the virtual with the real." Q5.

When questioned about examples of initiatives involving $A R$, only two teachers gave an example, the Côa Museum and the EduPARK project. It is interesting that the EduPARK project had been mentioned by four teachers as an example of mobile learning, but three of the respondents did not realize that it also involved AR.

Five teachers mentioned having had previous AR experience. From these, only three presented valid examples, in contexts as a teacher training of the EduPARK project, Science Museums or watching others using AR: "I've seen my son using the tablet with augmented reality" Q14. All teachers mentioned not having previous experience of using AR for their own learning.

No teacher had previous experience of using AR to promote his/her students' learning. They mentioned this attitude could change due to the motivator factor ( 5 teachers, as illustrates "It motivates students to more complicated contents, ...to increase their interest." Q5), a higher efficacy in teachinglearning (3 teachers, as shows the statement: "Enhancing the acquisition of knowledge in the area of mathematics." Q14), willingness to change practice (2 teachers, as shows "Possibility of change in teaching practice." Q4), knowing the process of using AR for learning (1 teacher, "To know this teaching-learning process." Q8) and the possibility of discussing the AR experience itself (1 teacher, "It opens the possibility of exploration and debate about the appearance of certain objects (or others) in places where they do not exist." Q13). Two teachers mentioned not knowing what could motivate them for using AR in their practice (e.g., "I don't know, I hope to know with the training." Q1).

Teachers reported one ( 5 teachers), two ( 2 teachers) or three AR advantages ( 2 teachers), in a total of 15 . Table 4 presents the themes of teachers' responses. It is possible to identify similarities with mobile devices advantages themes, e.g., motivation standing out. This similarity may be due to teachers already associating mobile devices to AR experiences. 
Table 4. Advantages of mobile learning, according to the participant teachers.

\begin{tabular}{l|l|c}
\hline \multicolumn{1}{c|}{ Advantage theme } & \multicolumn{1}{c}{ Example of citation } & Frequency \\
\hline Motivates students to learn & It must be very appealing to students. Q7 & 7 \\
\hline Better learning & Improves knowledge. Q9 & 4 \\
\hline Technology availability & The fact that they always have their cell phone with them. Q2 & 1 \\
\hline Learning in a fun way & Learning in a playful way. Q4 & 1 \\
\hline $\begin{array}{l}\text { Diversifies teaching/learning } \\
\text { methodologies }\end{array}$ & Learn new ways to teach. Q16 & 1 \\
\hline Experience sharing & Share experiences with colleagues. Q16 & 1 \\
\hline \hline
\end{tabular}

Teachers reported one (7 teachers), two (2 teachers) or three mobile learning barriers/constraints (1 teacher), in a total of 15 . Table 5 presents the themes of teachers' responses. It is clear teachers associate AR constraints to mobile devices constraints, as the main reported factors are related to this technology. As teachers generally indicated the same number of advantages and barriers for AR, this may indicate they have a neutral perspective for this technology they know less.

Table 5. Barriers/constraints of mobile learning, according to the participant teachers.

\begin{tabular}{l|l|c}
\hline \multicolumn{1}{c|}{ Barriers/constraints theme } & \multicolumn{1}{|c}{ Example of citation } & Frequency \\
\hline $\begin{array}{l}\text { Lack of access to mobile devices } \\
\text { and their diversity }\end{array}$ & $\begin{array}{l}\text { The school does not have many } \\
\text { technological means. Q15 }\end{array}$ & 5 \\
\hline Lack of (quality) Internet connection & $\begin{array}{l}\text { Constraints inherent to the Internet } \\
\text { connection. Q2 }\end{array}$ & 3 \\
\hline Teacher not knowing how to use it & Unawareness of how to use the tools. Q16 & 3 \\
\hline Access to distractions & Students' distraction. Q4 & 2 \\
\hline Lack of time & Lack of time. Q9 & 2 \\
\hline \hline & Total & 15 \\
\hline
\end{tabular}

\subsection{Teachers' previous experiences and perceptions on game-based learning}

When asked about the meaning of game-based learning, two teachers acknowledged not knowing. Two teachers presented definitions considered incorrect, three teachers presented definitions inaccurate and seven teachers presented simple but correct definitions, as illustrates the following citation: "The student learns through play, by gaming." Q9. When questioned about examples of game-based learning, five teachers mentioned five examples: games available at Mocho platform, EduPARK, Kahoot, Minecraft and Tangram.

Seven teachers mentioned having previous experience in using games for their own learning, through Phet, EduPARK, Kahoot, Quizes (2 teachers), and SuperTmatik.

Regarding the frequency with which teachers claim using game-based learning six selected "never used", another six "sometimes" and two "periodically". From the eight teachers that claimed to have promoted game-based learning at least once, six presented valid examples, usually in quiz format (e.g., "Quiz related to the Periodic Table" Q1). Teachers that never used games in their teaching practices mentioned that could change due to students' motivation (3 teachers), access to mobile devices, knowing educational games, and few resources available at school.

Teachers reported one (6 teachers), two ( 5 teachers) or three game-based learning advantages (3 teachers), in a total of 19. Table 6 presents the themes of teachers' responses and once again motivation stands out. Not surprisingly, fun learning is a theme that is present in all workshop topics but emerges more frequently in game-based learning. 
Table 6. Advantages of game-based learning, according to the participant teachers.

\begin{tabular}{l|l|c}
\hline \multicolumn{1}{c|}{ Advantage theme } & \multicolumn{1}{c|}{ Example of citation } & Frequency \\
\hline Motivates students to learn & $\begin{array}{l}\text { The possibility of learning as a challenge is } \\
\text { motivating for all. Q13 }\end{array}$ & 9 \\
\hline Learning in a fun way & It makes teaching more fun. Q16 & 5 \\
\hline Better learning & $\begin{array}{l}\text { It enhances reasoning, the relationship of } \\
\text { concepts, the taste for learning, ... Q1 }\end{array}$ & 3 \\
\hline Can be done without the teacher & It can be done without our physical presence. Q14 & 2 \\
\hline \hline & Total & 19 \\
\hline
\end{tabular}

Teachers reported one ( 6 teachers) or two (6 teachers) game-based learning barriers/constraints, in a total of 19, and one teacher mentioned there are no barriers/constraints. Table 7 presents the themes of teachers' responses. Lack of time to prepare or to teach content from the national standards were the most mentioned.

Table 7. Barriers/constraints of game-based learning, according to the participant teachers.

\begin{tabular}{l|l|c}
\hline \hline \multicolumn{1}{c|}{ Barriers/constraints theme } & \multicolumn{1}{|c}{ Example of citation } & Frequency \\
\hline Lack of time & Compliance with the discipline program. Q15 & 6 \\
\hline Lack of resources & $\begin{array}{l}\text { Availability of material resources in schools } \\
\text { for all classes. Q3 }\end{array}$ & 3 \\
\hline Poorer learning & $\begin{array}{l}\text { Difficulty of adapting to some students, for } \\
\text { various reasons. Q13 }\end{array}$ & 3 \\
\hline $\begin{array}{l}\text { Lack of access to mobile devices and } \\
\text { their diversity }\end{array}$ & Not having the mobile device. Q2 & 2 \\
\hline Lack of (quality) Internet connection & Internet connection /its cost. Q8 & 2 \\
\hline Addiction & Risk of student addiction. Q13 & 1 \\
\hline Other factors & Demotivation of the teaching class. Q16 & 1 \\
\hline & Total & 19 \\
\hline \hline
\end{tabular}

\section{CONCLUSIONS}

This exploratory study aims to know teachers' perceptions on mobile game-based learning with AR at the beginning of a 50-hour continuous training course, in workshop format, which was designed to promote collaborative development of mobile AR game-based resources for Science, Technology, Engineering and Mathematics learning. This initial snapshot will allow to evaluate the impact of the workshop in teachers' readiness to integrate mobile, AR and game-based in their practices.

This study results reveal that the workshop was attained by teachers with different profiles in what concerns technology conditions in schools towards the integration of mobile devices, AR and games in teaching. Most teachers of this experienced cohort enrolled in the Workshop to learn new teaching methodologies and to have access to new educational resources to use in their practices. Although the integration of digital technologies and game-based learning in teaching is advocated in the literature [2]-[4], [6], several participating teachers reported the school puts at their disposal outdated devices and unreliable Internet connection. This scenario seems even more difficult for students, as their access to technology provided by the school seems to be lower, when compared to teachers. This means that, to implement the strategies explored in the workshop, teachers need to follow the bring your own device (BYOD) approach. However, this option has the potential to increase the digital divide [13]-[15] among students whose families can afford technology and those who cannot, so caution is advised when planning the learning activities.

Most teachers revealed naïve or imprecise perspectives on mobile and game-based learning and were unaware of AR technologies and their potential use in education. For instance, teachers sometimes provided examples of mobile learning that revealed confusion regarding digital technology, in general, and mobile technology. Regarding previous experience, teachers' profiles varied from 
those who did not know and did not use either of the three approaches (in their teaching practices nor in their personal learning experiences) to those who seem to have somewhat accurate ideas and even some teaching experience. Therefore, according to teachers, they are starting to integrate mobile and game-based learning in their practices. This must be interpreted with caution, as not all of those who claim using mobiles and/or games provided valid examples. Nevertheless, the aim is to support teachers adopting more frequently both strategies, as well as their quality.

The fact that teachers generally indicated more constraints than advantages on mobile learning may indicate a negative perspective towards the use of mobile devices in their practices. Regarding games and $A R$ (the less known technology), teachers seem to have a neutral opinion, as they mentioned the same number of advantages and barriers.

The questions about factors that could motivate teachers to integrate mobile, AR and games in teaching practice, their advantages and their constraints provided coherent results. These indicate that teachers acknowledge in these strategies a high potential to promote students' motivation to learn and, consequently, to promote effective learning, sometimes in a fun way. However, a question arises: if teachers already acknowledge these factors, why are not they already implementing mobile, AR game-based learning with high regularity with their students? Analysing the reported barriers, it seems essential for teachers to make sure they and their students have access to resources, such as the devices themselves and good-quality internet connection [13]-[15]. In the case of games, it is important to know which educational resources can be implemented. Another constraint in the mind of almost half of the respondents is students' access to distractions.

Not surprisingly, AR exploration is the strategy teachers know less and have less experience with. Note that none declared have used it to learn or to promote their students learning before the workshop. In the case of this specific emerging technology, it is of primordial relevance to provide opportunities for teachers to experience learning with AR and to allow them to explore possibilities in terms of the teaching and learning processes.

The expectation is that the EduPARK app can be a good starting point to promote mobile AR gamebased learning, as this resource is open, free of charge and easy to use by teachers and their students. When teachers are engaged to contribute themselves to create a game, such as the case of this workshop, they become much more interested in implementing it with their students. In terms of research, this work is relevant as this study is an empirical account of teachers' perspectives and practices on mobile AR games with valuable results to implement it in the future.

Despite the group of teachers that participates in this study reflects the demographics of the Portuguese teaching profession, the results of this study need to be interpreted with caution and within the scope of this study. Further studies are needed with bigger and more diverse samples to better understand teachers' opinions on mobile game-based learning with AR. Another limitation of this study is the use of a convenient rather than random sample. This is due to accessibility issues concerning teachers' perspectives. Nevertheless, this study accomplished its purpose of eliciting teachers' opinions on mobile game-based learning with AR before teacher training on these topics. Future work should collect data with broader samples and should involve, as well, teachers' practices analysis, to triangulate teachers' statements with their effective practices.

\section{ACKNOWLEDGEMENTS}

This work is financially supported by National Funds through FCT - Fundação para a Ciência e a Tecnologia, I.P. under the project UIDB/00194/2020. The work of the first author is funded by national funds (OE), through FCT, in the scope of the framework contract foreseen in the numbers 4,5 and 6 of the article 23, of the Decree-Law 57/2016, of August 29, changed by Law 57/2017, of July 19.

\section{REFERENCES}

[1] P. Chow, "Teacher's Attitudes Towards Technology in the Classroom," University of Toronto, Toronto, 2015.

[2] D. Reid and N. Ostashewski, "iPads in the Classroom - New Technologies, Old Issues: Are they worth the effort?," EdMedia + Innov. Learn., vol. 2011, no. 1, pp. 1689-1694, 2011, Accessed: Jan. 17, 2021. [Online]. Available: https://www.learntechlib.org/primary/p/38089/. 
[3] J. Tessier, "Eliminating the Textbook: Learning Science With Cell Phones on JSTOR," J. Coll. Sci. Teaching, vol. 44, no. 2, pp. 46-51, 2014, Accessed: Jan. 17, 2021. [Online]. Available: https://www.jstor.org/stable/43631955?seq=1.

[4] L. Pombo and M. M. Marques, "The potential educational value of mobile augmented reality games: The case of edupark app," Educ. Sci., vol. 10, no. 10, 2020, doi: 10.3390/educsci10100287.

[5] L. Pombo, M. M. Marques, and V. Carlos, "Mobile augmented reality game-based learning: teacher training using the EduPARK app," Da Investig. às Práticas, vol. 9, no. 2, pp. 3-30, 2019, doi: 10.25757/invep.v9i2.182.

[6] P. A. Ertmer and A. T. Ottenbreit-Leftwich, "Teacher technology change: How knowledge, confidence, beliefs, and culture intersect," J. Res. Technol. Educ., vol. 42, no. 3, pp. 255-284, 2010, doi: 10.1080/15391523.2010.10782551.

[7] L. Pombo and M. M. Marques, "An App that Changes Mentalities about Mobile Learning-The EduPARK Augmented Reality Activity," Computers, vol. 8, no. 2, p. 37, May 2019, doi: 10.3390/computers8020037.

[8] R. K. Yin, Case study research: Design and Methods, 5th ed., no. May. Thousand Oaks: Sage Publications, 2014.

[9] Fundação Francisco Manuel dos Santos, "PORDATA - Docentes do sexo feminino em \% dos docentes em exercício nos ensinos pré-escolar, básico e secundário: total e por nível de ensino," PORDATA - Estatísticas, gráficos e indicadores de Municípios, Portugal e Europa, 2020. https://www.pordata.pt/Portugal/Docentes+do+sexo+feminino+em+percentagem+dos+docentes+ em+exercício+nos+ensinos+pré+escolar++básico+e+secundário+total+e+por+nível+de+ensino782 (accessed Sep. 15, 2020).

[10] Fundação Francisco Manuel dos Santos, "PORDATA - Índice de envelhecimento dos docentes em exercício nos ensinos pré-escolar, básico e secundário: por nível de ensino - Continente," PORDATA - Estatísticas, gráficos e indicadores de Municípios, Portugal e Europa, 2020. https://www.pordata.pt/Portugal/Índice+de+envelhecimento+dos+docentes+em+exercício++nos+ ensinos+pré+escolar++básico+e+secundário+por+nível+de+ensino+++Continente-944 (accessed Jan. 17, 2021).

[11] M. M. Marques and L. Pombo, "Game-Based Mobile Learning with Augmented Reality: Are Teachers Ready to Adopt It?," Proj. Des. Lit. as Cornerstones Smart Educ., no. 43, pp. 207-218, 2020, doi: 10.1007/978-981-13-9652-6_19.

[12] Conselho Nacional de Educação, "Estado da Educação 2019," Lisboa, 2020. [Online]. Available: https://www.cnedu.pt/content/edicoes/estado_da_educacao/EE2019_Digital_Site.pdf.

[13] 2007 Horizon Project Advisory Board, Horizon Report 2007 Edition (NMC and Educause). Stanford, CA: The New Media Consortium, 2007.

[14] L. Johnson, S. Adams, V. Estrada, and A. Freeman, NMC Horizon Report: 2015 K-12 Edition. Austin, Texas: The New Media Consortium, 2015.

[15] L. Johnson, R. Smith, A. Levine, and K. Haywood, 2010 Horizon Report: K-12 Edition. Austin, Texas: The New Media Consortium, 2010 